\title{
City Boardwalks: The Chance of Stalled Construction Sites
}

In Anthologies (http://www.ccities.org/category/publications/anthologies/),

Conscious Cities: Bridging_Neuroscience, Architecture, and Technology_(http://www.ccities.org/category/publications/anthologies/conscious-cities-bridging-neuroscience-archit Publications (http://www.ccities.org/category_publications/). by Dr Yeoryia Manolopoulou / May 3,

2017 / o Comments (http://www.ccities.org/city-boardwalks-chance-stalled-construction-sites/\#respond).
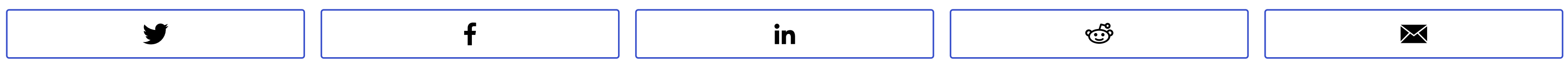

\section{Anchoring}

Cities sustain us because they have the capacity to provide us with relative stability, in material and emotional terms, against the complexities of life. We have confidence in the city because it 'anchors' our activities, thoughts, memories and plans to distinct places that we can easily recognise; we trust the city when it helps us orientate and navigate ourselves, creating meaningful physical and conceptual journeys between locations and times. We feel comfortable finding our way from the office to the station because we have followed the same route many times before and have gradually built in our minds an internal mental map of architectural landmarks: first I reach the bank, then I pass the post office where I turn right, then I walk further until I see the church, and so on.

The biological and cultural processes through which we perceive, learn, live, represent and mentally organise the city are complex. A neurological system of 'place cells' and 'grid cells' exists in the human brain that gives us the sense of place, direction and navigation guiding our movements in place and time'. In contrast, or in addition, anthropologists will say that it is the very narrative experience of stories and the association of these stories with specific places ('storied landscapes') that provides us with the human capacity to comprehend, navigate and remember the world ${ }^{2}$. Finally, for the role of memory and imagination in the making of the city, the architect Aldo Rossi has remarked: 'Now I seem to see all the things I have observed arranged like tools in a neat row; they are aligned as in a botanical chart, or a catalogue, or a dictionary. But this cataloguing between imagination and memory, is not neutral; it always reappears in several objects and constitutes their deformation, and in some way, their evolution'3. Cells, stories and built objects are all interrelated in an evolution of human processes that remarkably construct the city over time.

\section{Chancescape}

Cities are made to accommodate multiple changes, modes of living, rhythms, cycles and patterns of life, as well as chance relations and encounters. They are highly complex environments in a spatiotemporal sense, and it is mainly their temporality that enhances and adds synchronic and diachronic variation into even the most familiar and seemingly unchanged urban settings.

We may say that the city is ultimately defined as a chancescape: an environment that intermixes many different places, atmospheres, stories and circumstances. A chancescape does not exclude the rational logic that may have defined aspects of its built environment or the causality that may have brought about its social events. After all, chance can also be the intersection of trajectories that are born out of strict causality and order. Moreover, what someone perceives as an accident may be for someone else an entirely predictable event. It is precisely this tension between chance and necessity, accident and design, that makes city design and city life so fascinating ${ }^{4}$.

And thus, sometimes we like experiencing the city in a new way, we like being surprised and taken out of the ordinary.

\section{Leadenhall}


In addition, the project aimed to enhance the sites with large pots of plants installed where possible on other levels. The plants could inject a new aesthetic condition, a sense of seasonality, pleasure and wellbeing, and ultimately more biodiversity. The spacing and density of the pots would be variable and adaptable, so that clearings could be created to accommodate social gatherings, concerts or other events. The pots could easily be relocated to other sites when construction resumes. Beautiful transformations would occur when, for example, the perennial plants would bloom into bushy meadows in the summer.

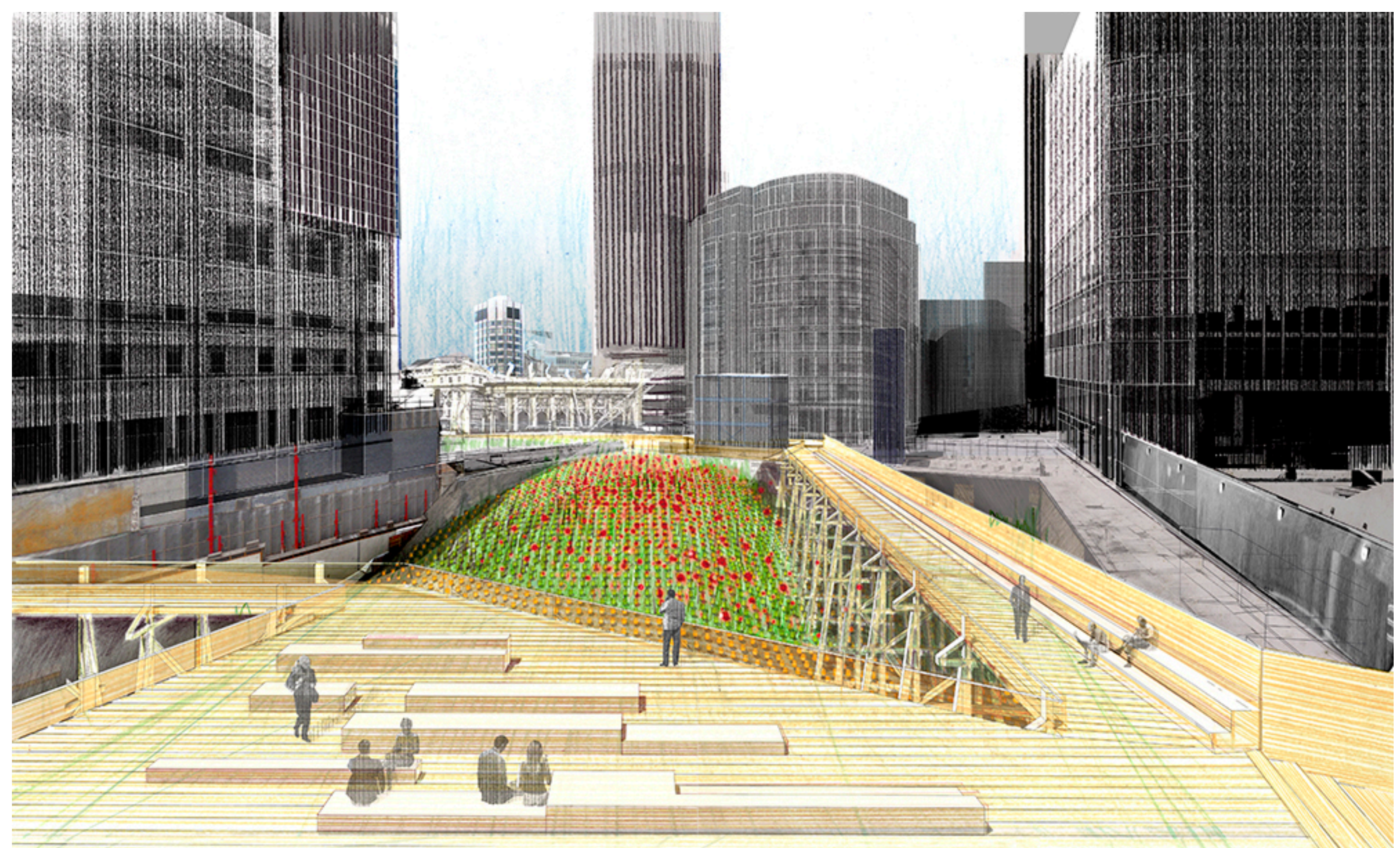

\section{Critical Design}

In this project we used critical design to challenge common commercial architectural expectations and to bring into synergy the ethics and poetics of circumstance, design and urban life. We took the chance of a circumstantial opportunity, contingent upon the financial crisis, to speculate about a conscious, perhaps improbable, urbanism. Turning pragmatic necessity to polemic proposition, we developed a strategy that could potentially alter urban habits providing new places for walking and, more importantly, for pausing. Boardwalks and pots could multiply and shift in stages. Bit by bit they would make a continuously adjustable matrix, connecting unused and stalled sites across the city. They would offer an environment of care, delightful perspectives, and entirely different ways of sensing the city coincidentally. New trajectories and stories would be lived and remembered, enriching our scaffold of memory and imagination.

The construction of the Leadenhall Tower was delayed but revived in 2010 when Oxford Properties co-developed the property in partnership with British Land. The Tower was eventually completed in 2014. 


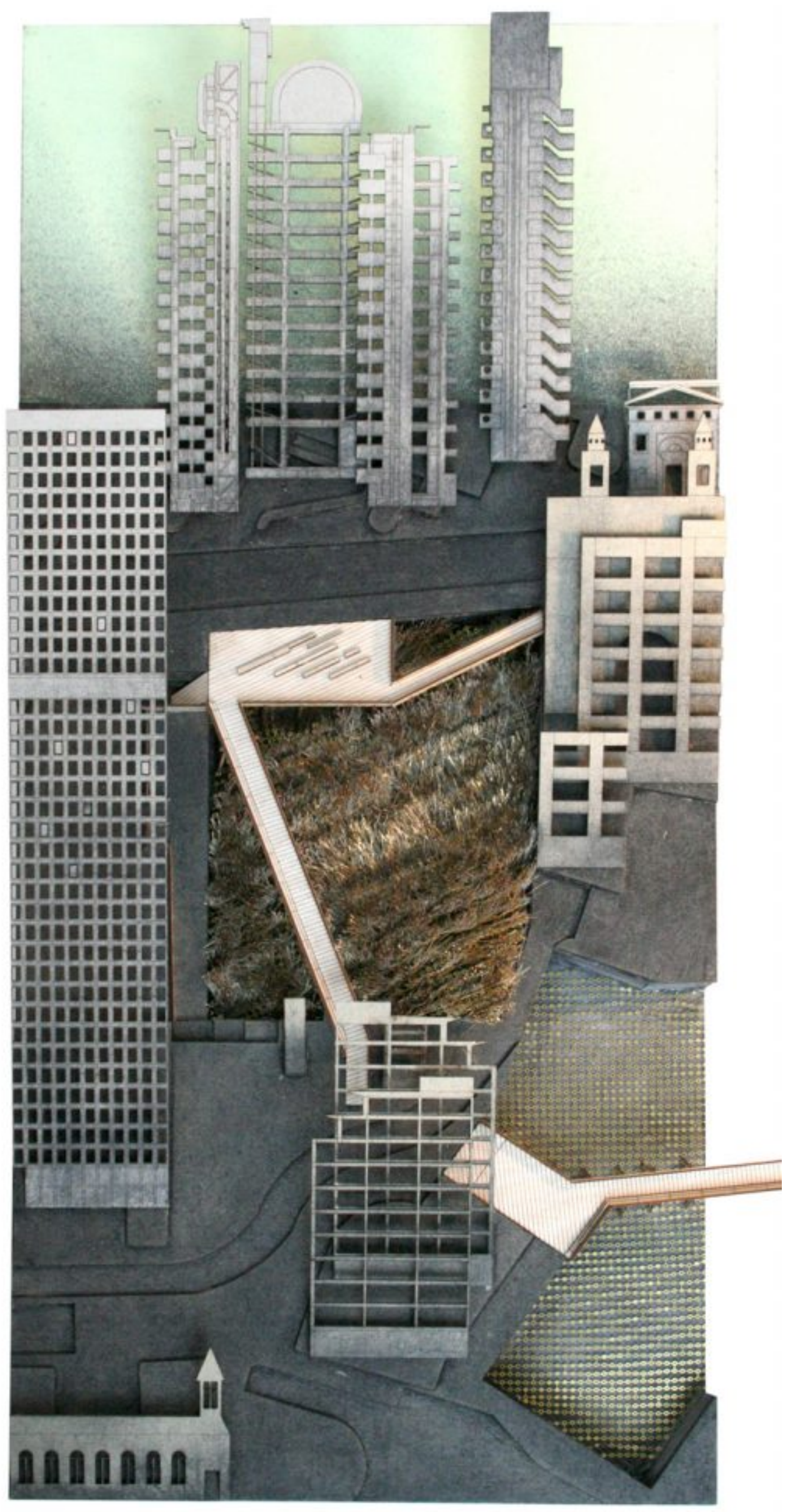

Notes

${ }^{1}$ Neuroscientists tell us that within the hippocampus of the brain we have an internal spatial mechanism that uses a matrix of firing neurons to give us a sense of place and position, and the ability to navigate and remember our environment. In 1971 John O'Keefe discovered 'place cells' in the human brain and in 2005 May-Britt Moser and Edvard I. Moser discovered 'grid cells' that create hexagonal lattices. These cells make map-like internal representations of the world onto which we store episodic memories.

${ }^{2}$ Read for example Tim Ingold's discussion about wayfinding in his The Perception of the Environment: Essays in Livelihood, Dwelling and Skill (London: Routledge, 2000), pp. 219-42.

${ }^{3}$ Aldo Rossi, A Scientific Autobiography (Cambridge: MIT Press, 1984), p. 23.

${ }^{4}$ I discuss in depth the critical and creative possibilities of chance in perception and design in Architectures of Chance (London: Routledge, 2013) where I define five types of 'impulsive', 'systematic', 'fabricated', 'active' and 'resistant' modes of chance contributing not only to the conception of a work but also to its perception and further existence.

${ }^{5}$ The site of 122 Leadenhall Street was previously occupied by the Peninsular and Oriental Tower, a building owned by the developer British Land and operating as a pair with the still existing Commercial Union Tower, now called St. Helen's. The 15-storey building, built in 1965, was demolished in 2007 in 
preparation for the development of a new skyscraper, popularly known as 'The Cheesegrater'.

${ }^{6} \mathrm{AY}$ Architects ranked in a finalist position in this competition. The scheme has been exhibited at the Building Centre and the Royal Academy of Arts in London. For more visit http://ayarchitects.com/project/122-leadenhall/

\section{Leave a Comment}

You must be logged in (http://www.ccities.org/wp-login.php?redirect to=http\%3A\%2F\%2Fwww.ccities.org\%2Fcity-boardwalks-chance-stalledconstruction-sites $\% 2 \mathrm{~F})$. to post a comment.
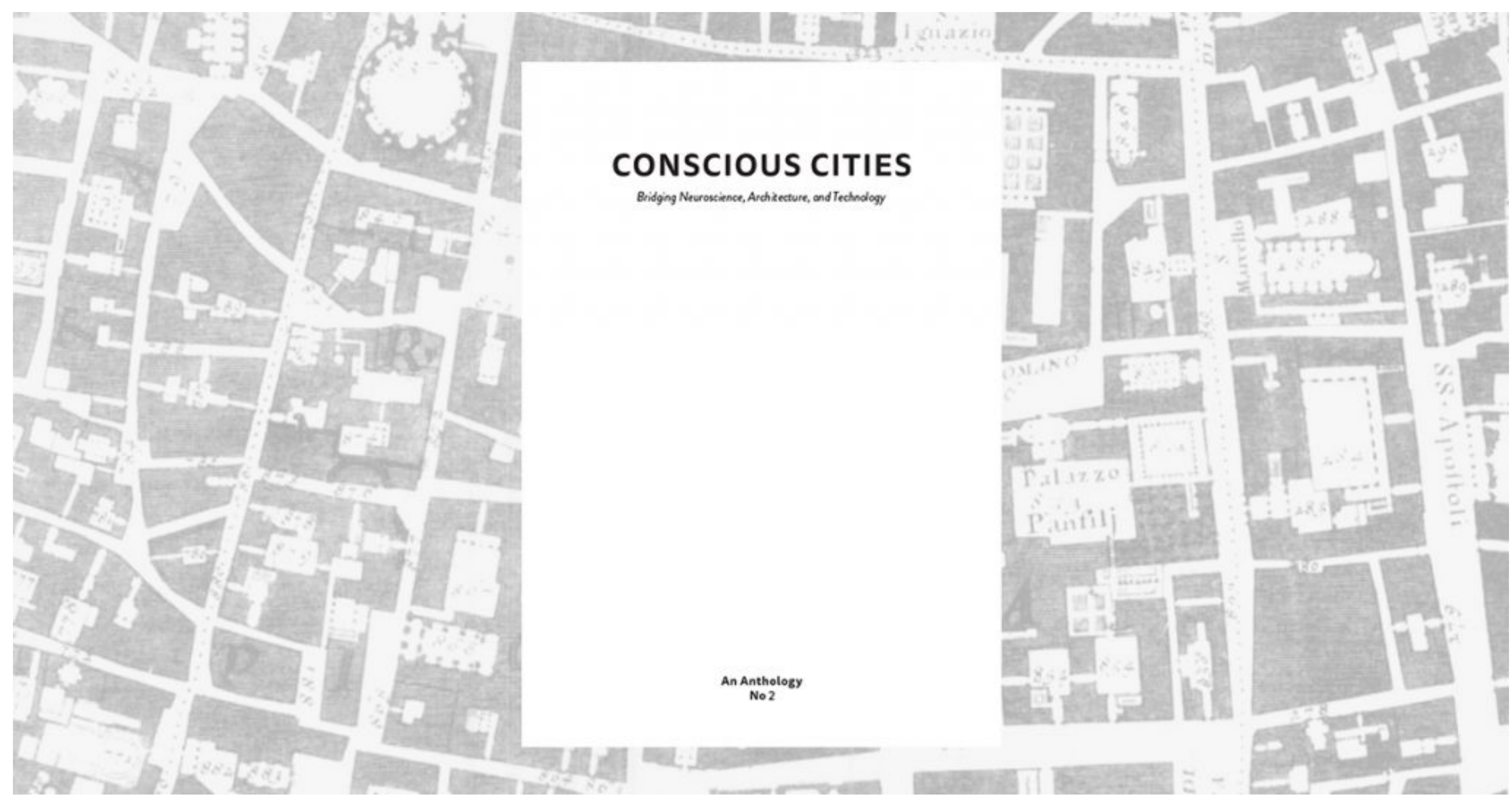

(http://www.ccities.org/publications/conscious-cities-bridging-neuroscience-architecture-technology/_).

DR YEORYIA MANOLOPOULOU

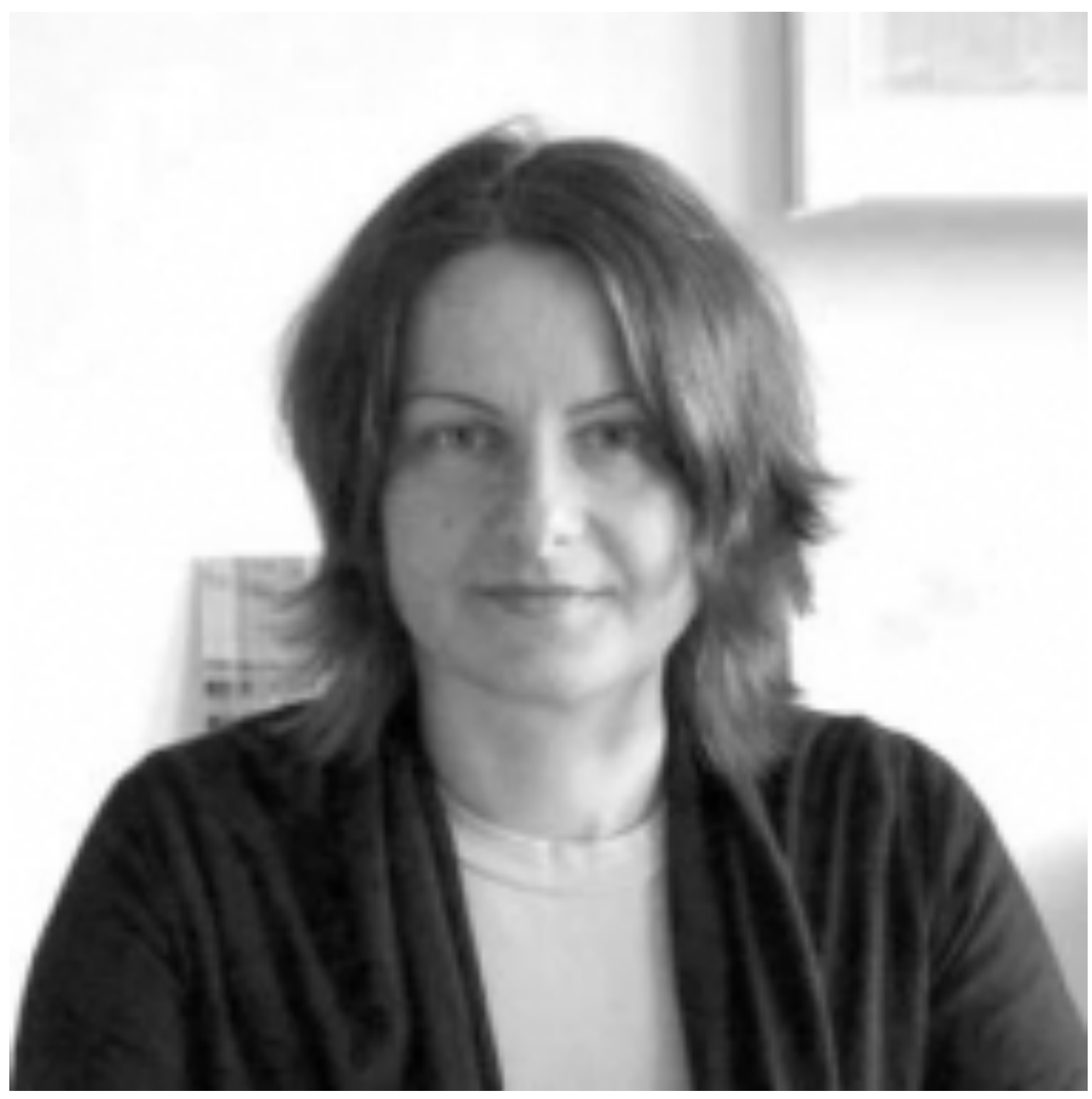


Dr Yeoryia Manolopoulou is an architect, researcher and educator; founding partner of the award-winning studio AY Architects and Director of Research at the Bartlett School of Architecture, UCL. Her practice received international attention with the installation House of Flags, erected on Parliament Square for London's Olympic Games. In 1013 AY Architects'Montpelier Community Nursery won the Stephen Lawrence Prize, a RIBA National Award and was mid-listed for the Stirling Prize. Yeoryia is the author of Architectures of Chance (Routledge 2013) and founding editor of the publication series Bartlett Design Research Folios. In 2014 she was shortlisted for the AJ's Emerging Woman Architect Award. She was co-author and curator of Losing Myself, the Irish Pavilion at the 2016 Venice Biennale.

SIGN UP TO OUR NEWSLETTER

Your email address

Sign up

MORE FROM THIS PUBLICATION

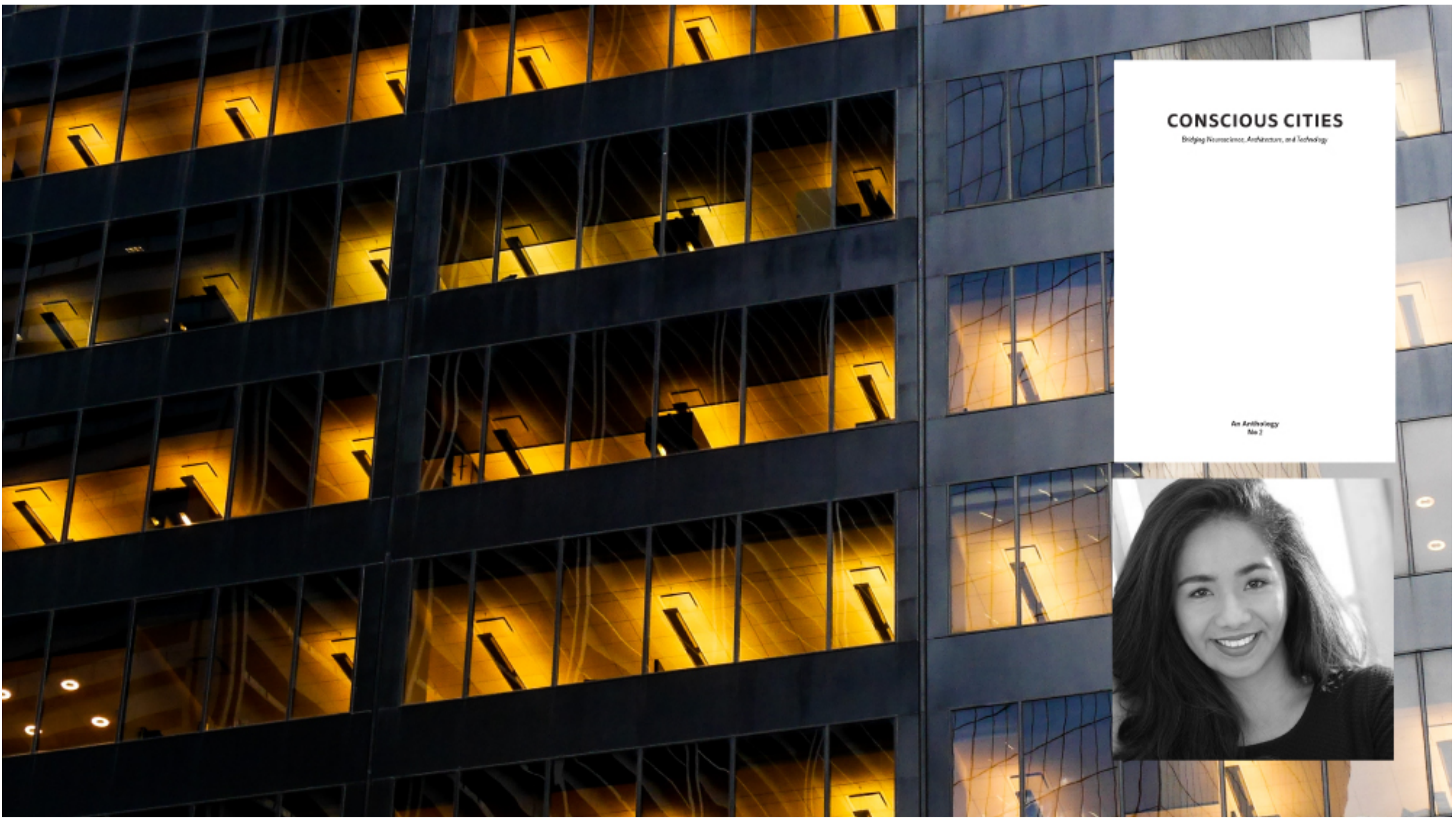

(http://www.ccities.org/light-space-review/).

Light and Space: A Review (http://www.ccities.org/light-space-review/)

by Araceli Camargo 


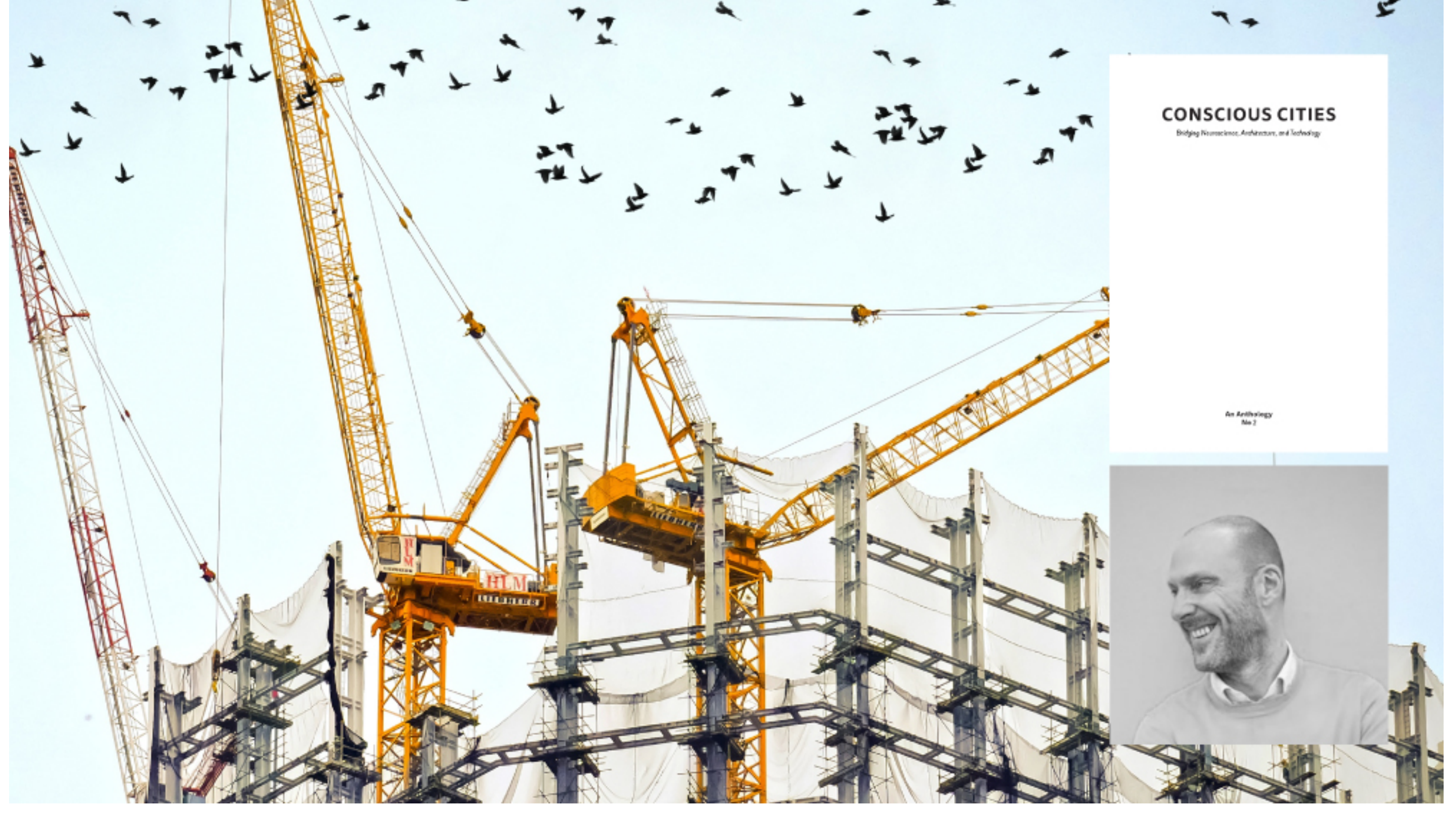

(http:///www.ccities.org/cant-property-development-good-business/).

Why Can't Property Development Be Good Business? (http://www.ccities.org/cant-property-development-good-business/)

by Martyn Evans

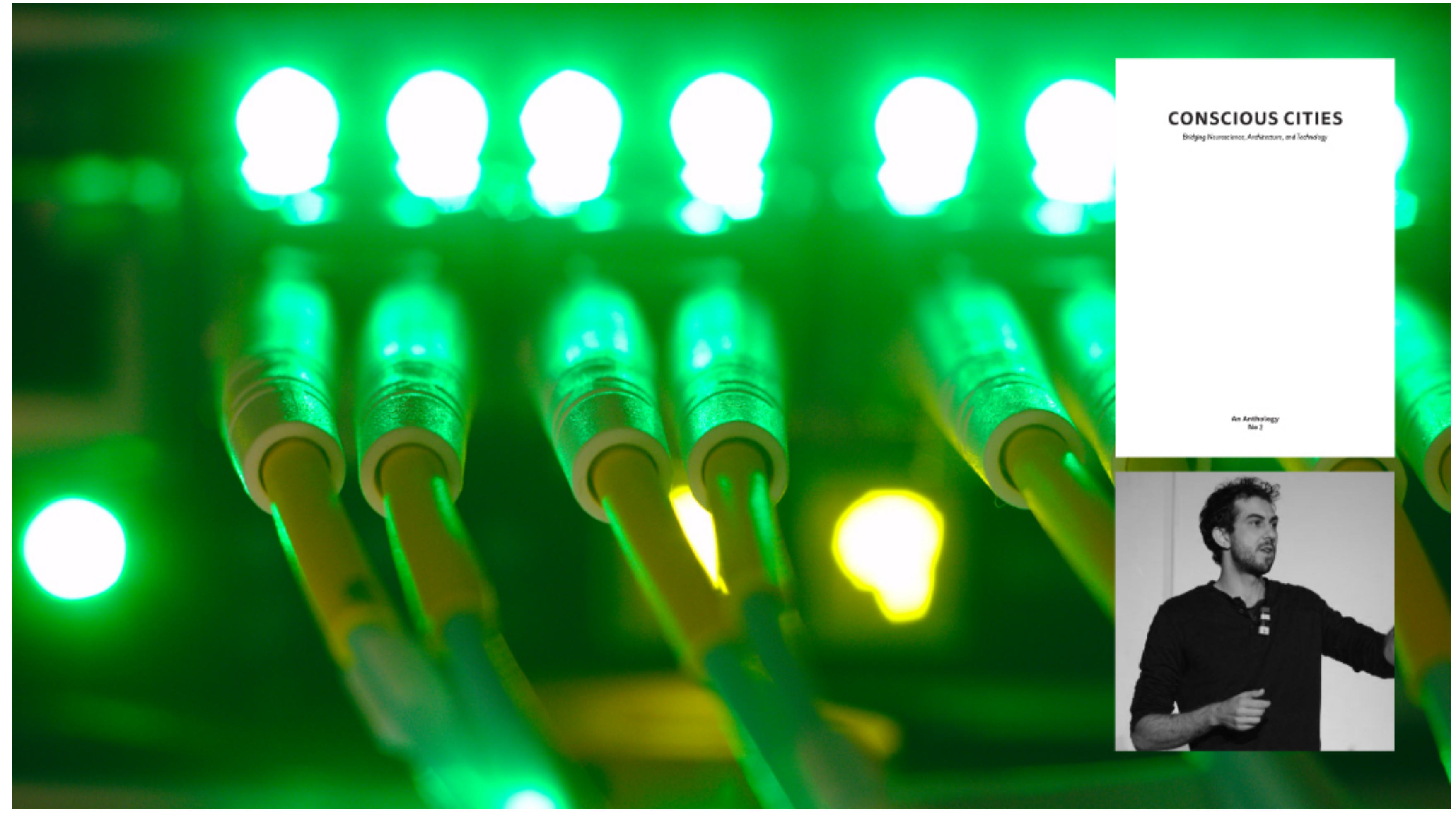

(.http://www.ccities.org/artificial-intelligence-environment/).

Artificial Intelligence in our Environment (http://www.ccities.org/artificial-intelligence-environment/)

by Daniel Hulme 
